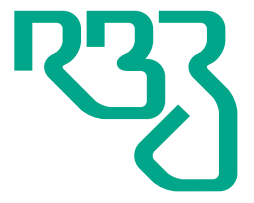

\section{Revista}

Brasileira de

Zootecnia

Brazilian Journal of Animal Science

ISSN 1806-9290

www.rbz.org.br

\title{
Do live or inactive yeasts improve cattle ruminal environment?
}

\author{
Camila Soares Cunha $^{1^{*}}$ (iD), Marcos Inácio Marcondes ${ }^{\mathbf{1}}$ (iD), Alex Lopes da \\ Silva $^{2}$ iD, Tathyane Ramalho Santos Gionbelli ${ }^{3}$, Marco Aurélio Schiavo \\ Novaes $^{1}$, Leonardo Sidney Knupp ${ }^{4}$, Gercino Ferreira Virginio Júnior ${ }^{5}$ (iD), \\ Cristina Mattos Veloso ${ }^{1}$ iD \\ ${ }^{1}$ Universidade Federal de Viçosa, Departamento de Zootecnia, Viçosa, MG, Brasil. \\ ${ }^{2}$ Universidade Federal Rural do Rio de Janeiro, Departamento de Produção Animal, \\ Seropédica, RJ, Brasil. \\ ${ }^{3}$ Universidade Federal de Lavras, Departamento de Zootecnia, Lavras, MG, Brasil. \\ ${ }^{4}$ Universidade Federal da Paraíba, Departamento de Zootecnia, Areia, PB, Brasil. \\ ${ }^{5}$ Universidade de São Paulo, Escola Superior de Agricultura "Luiz de Queiroz", Piracicaba, SP, \\ Brasil.
}

*Corresponding author:
camilasoares4@yahoo.com.b

Received: October 19, 2018

Accepted: April 22, 2019

How to cite: Cunha, C. S.; Marcondes, M. I.; Silva, A. L.; Gionbelli, T. R. S.; Novaes, M. A. S.; Knupp, L. S.; Virginio Júnior, G. F. and Veloso, C. M. 2019. Do live or inactive yeasts improve cattle ruminal environment? Revista Brasileira de Zootecnia 48:e20180259.

https://doi.org/10.1590/rbz4820180259

Copyright: This is an open access article distributed under the terms of the

Creative Commons Attribution License (http://creativecommons.org/licenses/by/4.0/) which permits unrestricted use, distribution, and reproduction in any medium, provided the original work is properly cited.
ABSTRACT - This research was conducted to investigate the effect of live and inactive sugarcane yeast on beef cattle voluntary intake, apparent digestibility of nutrients, ruminal $\mathrm{pH}$, volatile fatty acids (VFA) concentrations, and ruminal ammonia. Five rumen-cannulated Nellore heifers were distributed in a $5 \times 5$ Latin square design, with five experimental periods of 15 days, with seven days for adaptation to the additives and the remaining days for data records and sampling. Total mixed ration (TMR) was composed by corn silage (20\%) and concentrate (80\%) based on corn and soybean meal. Five treatments were evaluated: without additive use (negative control; NC); chemical buffer addition $-0.71 \%$ in concentrate DM of sodium bicarbonate and $0.18 \%$ of magnesium oxide (positive control, PC); $10 \mathrm{~g}$ /day live yeast (LY); $15 \mathrm{~g} /$ day of inactive yeast (IY15); and $30 \mathrm{~g} /$ day of inactive yeast (IY30). Sugarcane yeasts were directly infused in rumen immediately after morning and afternoon feed supply. Feed additives did not affect voluntary intake, nutrient digestibility, and sorting behavior of animals. However, heifers from all treatments presented preferential intake of fibrous fraction of diet, especially those from NC and IY15. Nitrogen balance, VFA concentrations, and blood parameters were not influenced as well. Sodium bicarbonate and magnesium oxide led to greater ruminal $\mathrm{pH}$ than yeast, and IY15 presented greater $\mathrm{pH}$ than IY30. Ruminal ammonia was increased by the use of additives. Active and inactive yeasts are not recommended as feed additives for bovines fed diets with $80 \%$ of concentrate since it allows animals to select fibrous particles from TMR, and no representative gain in ruminal parameters and digestibilities are guaranteed.

\section{Introduction}

Aiming to avoid the negative effects caused by acidosis, several additives are used to minimize ruminal pH reduction (González et al., 2012). Buffers, such as sodium bicarbonate, or alkaliers, as magnesium oxide, can be used individually or in association and are examples of feed commercial additives. In addition, a number of products such as yeast cultures and live or inactive yeasts have been used to maintain ruminal pH within the acceptable range (Williams et al., 1991; Opsi et al., 2012). 
Previous research has demonstrated that live yeasts are able to stabilize ruminal $\mathrm{pH}$ either by competing for substrates with lactate-producing bacteria, such as Streptococcus bovis (Williams et al., 1991; Chaucheyras et al., 1996), or by stimulating lactic acid-utilizing bacteria, such as Selenomonas ruminantium and Megasphaera elsdenii (Callaway and Martin, 1997). Inactive yeasts, on the other hand, may act only by providing stimulatory factors to ruminal bacteria, since they are a rich source of vitamins, enzymes, and cofactors (Dawson et al., 1990), and it is reasonable to think that their supplementation might need higher dosages to offset their lack of biological activity aiming an improvement of their action in rumen. These data indicate the potential of live and inactive yeasts as additives to control acidosis. However, data on yeast as ruminal buffer are inconclusive, and the wide range of strains, composition of commercial products, and supplementation levels (Williams et al., 1991; Wallace, 1996) used in studies have made it problematic to produce a significant compilation of results.

Yeasts have been studied as rumen buffers for beef and dairy cattle and small ruminants (Malcolm and Kiesling, 1990; Michalet-Doreau et al., 1997; Chung et al., 2011), but results are variable. While some have reported minimal effects of yeasts on ruminal fermentation (Malcolm and Kiesling, 1990), others found that yeasts are able to stimulate voluntary intake and influence ruminal stoichiometry (Williams et al., 1991) and show potential to reduce the risk of acidosis and improve fiber digestibility (Guedes et al., 2008). Comparing live and inactive yeasts on the same study, few data (Vyas et al., 2014a; Vyas et al., $2014 \mathrm{~b}$ ) are present in literature, mainly in vivo. Vyas et al. (2014a) studied the use of $4 \mathrm{~g} /$ day of active and inactive dried yeasts and concluded that the studied yeasts were not able to improve rumen $\mathrm{pH}$ or dry matter intake. However, the same researchers (Vyas et al., 2014b), testing the same treatments, found effects of active and inactive yeasts in reducing rumen $\mathrm{pH}$ and acidosis. They also emphasized that more research is needed to elucidate yeast mechanisms in the rumen, since concentration and profile of volatile fatty acids (VFA) were not affected by the additives. Oeztuerk and collaborators (Oeztuerk et al., 2005; Oeztuerk, 2009) and Opsi et al. (2012) published some in vitro research on this topic, but results were inconsistent, highlighting a need for further studies to clarify the real potential of yeasts as well as dosages that should be recommended.

We hypothesize that the use yeasts as feed additives in cattle diets can improve cattle voluntary intake, digestibility, and ruminal traits; active and inactive yeasts promote similar nutrient intake, digestibility, and lead to similar ruminal environment; and a higher dosage of inactive yeast is necessary to improve voluntary intake, nutrient digestibility, and ruminal characteristics in comparison with a smaller dosage. Therefore, our objective was to investigate the effect of live and inactive yeasts on cattle voluntary intake and apparent digestibility of nutrients as well as on ruminal traits $\left(\mathrm{pH}, \mathrm{VFA}, \mathrm{N}-\mathrm{NH}_{3^{\prime}}\right.$ and microbe protein synthesis).

\section{Material and Methods}

This research was approved by the institutional Committee on Animal Use (case number 42/2012) and was conducted in Viçosa, Minas Gerais, Brazil (2045'14" S; 4252'55" W; and 648 m).

Five rumen-cannulated Nellore heifers with approximately two years of age and initial live weight of $300 \pm 39.4 \mathrm{~kg}($ mean $\pm \mathrm{SD})$ were distributed in a $5 \times 5$ Latin square design, with five experimental periods of 15 days, with seven days for adaptation to the additives and the remaining days for data records and sampling. Animals were kept in tie stall barns with water provided ad libitum.

Five treatments were evaluated as follows: without additive use (negative control); chemical buffer addition $-0.71 \%$ in concentrate DM of sodium bicarbonate and $0.18 \%$ of magnesium oxide (positive control); $10 \mathrm{~g} /$ day live yeast (LY); $15 \mathrm{~g} /$ day of inactive yeast (IY15); and $30 \mathrm{~g} /$ day of inactive yeast (IY30).

The total mixed ration (TMR) was composed by corn silage $(20 \%)$ and concentrate (80\%) based on corn and soybean meal (Table 1); it was offered twice daily at 07.00 and $15.00 \mathrm{~h}$ and was formulated according to NRC (2000) for a gain of $1.20 \mathrm{~kg} / \mathrm{animal} /$ day, and daily amounts of food supplied allowed 5 to $10 \%$ of refusals. 
Sugarcane yeasts from Saccharomyces cerevisiae were acquired from a commercial source. According to manufacturer, both products contain at least 20 billion cells per gram, in which live cells are present on LY $\left(2.0 \times 10^{10} \mathrm{cfu} / \mathrm{g}\right)$, while inactive cells compose IY. Yeasts were directly infused in the rumen immediately after morning and afternoon feed supply to guarantee total intake. Half of the daily dosage was pre-weighed in paper cartridges, and one cartridge was used after each feeding. Sodium bicarbonate and magnesium oxide were mixed to the concentrate while it was being produced.

Corn silage and refusals were sampled for six days: corn silage from the 8th to the 13th day, and refusals from the 9th to the 14th day of each period. Ingredients of the concentrate were sampled at the feed mills once per period. By the end of each period, representative samples (DM basis) from each animal were made and frozen until analysis.

Feces samples were taken at days 9,11 , and 13 for $24 \mathrm{~h}$ each. By the end of each day, $5 \%$ of the total fecal mass of each animal was sampled, weighed, and pre-dehydrated.

Feedstuffs, refusals, and feces samples were processed in knife mills with 1-mm screen sieves and analyzed for its contents of dry matter (DM; method 934.01; AOAC, 1990), organic matter (OM; method 942.05; AOAC, 1990), crude protein (CP; method 920.87; AOAC, 1990), and ether extract (EE; method 920.39 AOAC, 2006). Neutral detergent fiber (NDF) was analyzed according to Detmann et al. (2012), method INCT-CA F-001/1. Ash correction was performed in the NDF residues (INCT-CA M-002/1) and for protein residues (NDFap) according to Licitra et al. (1996). Non-fiber carbohydrates (NFC) were calculated as proposed by Detmann and Valadares Filho (2010). From these data, intake and apparent digestibility of the fractions of diets were calculated. Contents of NDFap, CP, and NFC on feedstuffs and refusals were used to assess the sorting behavior of animals. It was calculated as the actual intake of each fraction in relation to the predicted intake. Values $<100 \%$ indicate selective refusals (sorting against), $>100 \%$ indicate preferential intake (sorting for), and $=100 \%$ indicate no sorting (Leonardi and Armentano, 2003; Silva et al., 2018).

Ruminal fluid and blood samples were collected on the 14th day at 06.00, 12.00; 18.00, and 00:00 $\mathrm{h}$. Ruminal content was filtered in four layers of cheesecloth, and $\mathrm{pH}$ measurement was immediately performed in rumen fluid using a digital potentiometer. Additionally, rumen ammonia nitrogen $\left(\mathrm{NH}_{3}-\mathrm{N}\right)$

Table 1 - Ingredient proportion and chemical composition of the experimental diets

\begin{tabular}{|c|c|c|c|c|}
\hline \multirow{2}{*}{ Item } & \multicolumn{2}{|c|}{ Without $\mathrm{NaHCO}_{3}+\mathrm{MgO}$} & \multicolumn{2}{|c|}{ With $\mathrm{NaHCO}_{3}+\mathrm{MgO}$} \\
\hline & Concentrate & Diet & Concentrate & Diet \\
\hline \multicolumn{5}{|l|}{ Ingredient (g/kg) } \\
\hline Corn silage & & 200.00 & & 200.00 \\
\hline Ground corn & 828.00 & 662.40 & 809.70 & 647.80 \\
\hline Soybean meal & 149.50 & 119.60 & 155.30 & 124.20 \\
\hline Mineral mixture & 0.20 & 0.20 & 0.20 & 0.20 \\
\hline Limestone & 10.00 & 8.00 & 10.00 & 8.00 \\
\hline Sodium bicarbonate & - & - & 7.10 & 5.70 \\
\hline Magnesium oxide & - & - & 1.80 & 1.40 \\
\hline Sodium chloride & 2.70 & 2.20 & 6.10 & 4.90 \\
\hline Urea & 9.30 & 7.40 & 9.40 & 7.50 \\
\hline \multicolumn{5}{|l|}{ Chemical composition } \\
\hline \multirow[t]{2}{*}{ Dry matter (g/kg as fed) } & 861.00 & 740.00 & 863.00 & 740.00 \\
\hline & \multicolumn{4}{|c|}{$\mathrm{g} / \mathrm{kg}$ of DM } \\
\hline Organic matter & 967.00 & 960.00 & 954.00 & 95.00 \\
\hline Crude protein & 175.00 & 150.00 & 176.00 & 150.00 \\
\hline Ether extract & 28.00 & 20.00 & 28.00 & 20.00 \\
\hline NDFap & 122.00 & 200.00 & 120.00 & 200.00 \\
\hline Non-fiber carbohydrates & 657.00 & 590.00 & 646.00 & 580.00 \\
\hline Ash & 33.00 & 40.00 & 46.00 & 50.00 \\
\hline
\end{tabular}

NDFap - neutral detergent fiber corrected for ashes and protein 
analysis was performed, in which $50 \mathrm{~mL}$ of rumen fluid was preserved in a 1:1 solution of sulfuric acid. Analysis was performed as described by Chaney and Marbach (1962). An aliquot of $10 \mathrm{~mL}$ of rumen fluid from each sampling time was preserved in $10 \mathrm{~mL}$ of metaphosphoric acid $25 \%$ for VFA evaluation, as described by Siegfried et al. (1984), by high-performance liquid chromatography.

Blood samples were centrifuged at $2500 \mathrm{rpm}$ for $20 \mathrm{~min}$, and the serum was used for analyzes of glucose, urea nitrogen, and creatinine. Glucose and creatinine concentrations were evaluated by the colorimetric enzymatic method, and urea content was analyzed by the ultraviolet method, with an automatic Cobas Mira - Roche ${ }^{\circledR}$ equipment. These analyzes were performed using commercial kits (Labtest Diagnóstica S. A., Lagoa Santa, Minas Gerais, Brazil).

On the 15th day, two spot urine samples were taken before the morning and afternoon meals. Samples were filtered in three layers of cheesecloth, and $10 \mathrm{~mL}$ aliquots were diluted in $40 \mathrm{~mL}$ of sulfuric acid $0.036 \mathrm{~N}$ (Valadares et al., 1999). Samples pH were adjusted to values lower than 3 and were analyzed for the total nitrogen (method 920.87; AOAC, 1990), creatinine, urea, allantoin, and uric acid contents. Creatinine was used for estimation of urinary volume, as described by Silva et al. (2012), and was determined by the colorimetric enzymatic method. Ultraviolet methodology was used for urea analysis. Labtest commercial kits were used in creatinine and urea analyses. Allantoin analysis was performed according to the technique of Fujihara et al. (1987), described by Chen and Gomes (1992). Uric acid was analyzed by the colorimetric method with the aid of a commercial kit (In Vitro Diagnostica ${ }^{\circledR}$ ).

Ruminal protein synthesis was estimated as proposed by Chen and Gomes (1992). Absorbed microbial purines (AMP) and the intestinal flow of microbial nitrogen compounds (Nmic) were calculated as described by Barbosa et al. (2011). The nitrogen balance was estimated as the difference between the total nitrogen intake and fecal and urinary nitrogen excretions.

The measured variables were evaluated by the mixed model:

$$
\mathrm{Y}_{\mathrm{ijk}}=\mu+\beta_{\mathrm{i}}+\mathrm{c}_{\mathrm{j}}+\mathrm{d}_{\mathrm{k}}+\mathrm{e}_{\mathrm{ij} \mathrm{k}^{\prime}}
$$

in which $Y_{i j k}=$ response variable, $\mu=$ overall mean, $\beta_{i}=$ effect of the treatment i (fixed effect), $c_{j}=$ effect of the animal $j$ (random effect), $d_{k}=$ effect of period $k$ (random effect), and $e_{i j k}=$ random error with mean 0 and variance $\sigma^{2}$.

Rumen $\mathrm{pH}, \mathrm{N}-\mathrm{NH}_{3}$, and blood parameters were added to the model as repeated measures using the following statistical model:

$$
\mathrm{Y}_{\mathrm{ijklm}}=\mu+\beta_{\mathrm{i}}+\mathrm{t}_{\mathrm{ij}}+\tau_{\mathrm{k}}+(\beta \tau)_{\mathrm{ik}}+\mathrm{c}_{1}+\mathrm{d}_{\mathrm{m}}+\mathrm{e}_{\mathrm{ijk} \mathrm{km}}
$$

in which $Y_{i j k l m}=$ response variable; $\mu=$ overall mean; $\beta_{i}=$ effect of the treatment $\mathrm{i}$ (fixed effect); $t_{i j}=$ random error with mean 0 and variance $\sigma^{2}$, the variance among animals within treatment and it is equal to the covariance among repeated measures within animals; $\tau_{\mathrm{k}}=$ effect of time $\mathrm{k}$ (fixed effect); $(\beta \tau)_{i k}=$ interaction between treatment $\mathrm{i}$ and time $\mathrm{k} ; \mathrm{c}_{1}=$ effect of the animal $\mathrm{l}$ (random effect); $\mathrm{d}_{\mathrm{m}}=$ effect of period $\mathrm{m}$ (random effect); and $\mathrm{e}_{\mathrm{ijklm}}=$ random error with mean 0 and variance $\sigma^{2}$, the variance between measurements within animals.

For this model, the same seventeen variance covariance structures $[\operatorname{ANTE}(1), \operatorname{AR}(1), \operatorname{ARH}(1)$, ARMA(1,1),CS, CSH, FA(1), FA(2), TOEP, TOEP(2), TOEPH, TOEPH(2), UN, UN(1), UN(2), VC] were tested, and TOEP provided the best fit based on Akaike's information criteria.

Statistical analyzes were performed using the Restrict Maximum Likelihood method (PROC MIXED) of SAS software (Statistical Analysis System, University Edition) adopting 5\% as critical level of probability for the type I error. The following orthogonal contrasts were used to evaluate the results:

Need for buffers = NC vs buffered diets; chemical vs yeast buffers = PC vs yeast treatments; live vs inactive yeasts $=\mathrm{LY}$ vs inactive yeast treatments; and dose of inactive yeast = IY15 vs IY30. 


\section{Results}

Feed additives did not affect $(\mathrm{P}>0.05) \mathrm{DM}$ and digestible OM intake of beef heifers (Table 2). Intake of CP, EE, NDFap, and NFC were not influenced by treatments as well. Similar results were observed regarding total apparent digestibility. Digestibilities of DM, OM, CP, NDFap, and NFC did not differ $(P>0.05)$ among the treatments (Table 2). No differences were observed in sorting behavior of NDFap, CP, and NFC (Table 2); however, all treatments sorted against NFC and in favor of NDFap.

Regarding nitrogen balance (Table 3), effects of treatments were not observed ( $\mathrm{P}>0.05$ ) for the evaluated variables nitrogen intake (NI), fecal excretion of nitrogen (FEN), urinary excretion of nitrogen (UEN), nitrogen balance (NB), urinary urea nitrogen (UUN), efficiency of nitrogen utilization in relation to nitrogen intake (ENU1) and to absorbed nitrogen (ENU2), and microbial efficiency (MICEF).

Table 2 - Nutrient intake, total apparent digestibility, and sorting behavior of cows fed the experimental diets

\begin{tabular}{|c|c|c|c|c|c|c|c|c|c|c|}
\hline \multirow{2}{*}{ Variable } & \multicolumn{5}{|c|}{ Treatment $^{1}$} & \multirow{2}{*}{ SE } & \multicolumn{4}{|c|}{ Contrast - P-value } \\
\hline & $\mathrm{NC}$ & PC & LY & IY15 & IY30 & & $\mathrm{NC} \times \mathrm{BD}$ & PC $\times$ Yeast & $\mathrm{LY} \times \mathrm{IY}$ & IY15×IY30 \\
\hline \multicolumn{11}{|c|}{ Intake (kg/day) } \\
\hline $\mathrm{DM}$ & 5.42 & 5.27 & 5.54 & 5.72 & 5.48 & 0.84 & 0.83 & 0.44 & 0.89 & 0.65 \\
\hline $\mathrm{OM}$ & 5.22 & 5.00 & 5.33 & 5.51 & 5.28 & 0.80 & 0.87 & 0.35 & 0.89 & 0.65 \\
\hline dOM & 4.02 & 3.88 & 4.16 & 4.20 & 4.06 & 0.57 & 0.83 & 0.38 & 0.92 & 0.72 \\
\hline $\mathrm{CP}$ & 0.79 & 0.75 & 0.79 & 0.81 & 0.78 & 0.11 & 0.96 & 0.45 & 0.90 & 0.69 \\
\hline NDFap & 1.13 & 1.07 & 1.10 & 1.15 & 1.10 & 0.16 & 0.74 & 0.49 & 0.77 & 0.63 \\
\hline NFC & 3.13 & 2.95 & 3.26 & 3.37 & 3.22 & 0.51 & 0.78 & 0.23 & 0.89 & 0.65 \\
\hline \multicolumn{11}{|c|}{ Apparent digestibility (g/g) } \\
\hline DM & 0.765 & 0.769 & 0.773 & 0.765 & 0.764 & 1.92 & 0.59 & 0.69 & 0.38 & 0.86 \\
\hline $\mathrm{OM}$ & 0.779 & 0.781 & 0.787 & 0.779 & 0.777 & 1.96 & 0.90 & 0.99 & 0.57 & 0.92 \\
\hline $\mathrm{CP}$ & 0.752 & 0.755 & 0.769 & 0.755 & 0.749 & 1.10 & 0.69 & 0.80 & 0.14 & 0.65 \\
\hline NDFap & 0.665 & 0.671 & 0.661 & 0.654 & 0.634 & 2.86 & 0.68 & 0.40 & 0.53 & 0.52 \\
\hline NFC & 0.829 & 0.819 & 0.838 & 0.830 & 0.828 & 2.35 & 0.99 & 0.48 & 0.62 & 0.92 \\
\hline \multicolumn{11}{|c|}{ Sorting behavior (g/g) } \\
\hline NDFap & 1.09 & 1.03 & 1.02 & 1.07 & 1.00 & 0.06 & 0.27 & 0.97 & 0.71 & 0.27 \\
\hline $\mathrm{CP}$ & 0.99 & 0.96 & 0.95 & 0.94 & 0.95 & 0.02 & 0.07 & 0.70 & 0.79 & 0.68 \\
\hline $\mathrm{NFC}$ & 0.96 & 0.96 & 0.98 & 0.97 & 0.99 & 0.03 & 0.47 & 0.36 & 0.83 & 0.50 \\
\hline
\end{tabular}

${ }^{1} \mathrm{NC}=$ negative control; $\mathrm{PC}=$ positive control; $\mathrm{LY}=$ live yeast; $\mathrm{IY} 15$ = inactive yeast $15 \mathrm{~g} /$ day; IY30 = inactive yeast $30 \mathrm{~g} / \mathrm{day}$.

DM - dry matter; OM - organic matter; dOM - digestible organic matter; CP - crude protein; NDF - neutral detergent fiber corrected for ashes and protein; NFC - non-fiber carbohydrates; BD - buffered diets; SE - standard error.

Table 3 - Nitrogen balance, efficiency of nitrogen utilization, and microbial efficiency in cattle fed the experimental diets

\begin{tabular}{|c|c|c|c|c|c|c|c|c|c|c|}
\hline \multirow{2}{*}{ Variable } & \multicolumn{5}{|c|}{ Treatment $^{1}$} & \multirow{2}{*}{ SE } & \multicolumn{4}{|c|}{ Contrast - P-value } \\
\hline & $\mathrm{NC}$ & $\mathrm{PC}$ & $L Y$ & IY15 & IY30 & & $\mathrm{NC} \times \mathrm{BD}$ & PC $\times$ Yeast & $L Y \times I Y$ & IY15×IY30 \\
\hline NI (g/day) & 125.94 & 120.49 & 126.41 & 130.14 & 119.38 & 17.36 & 0.82 & 0.58 & 0.86 & 0.36 \\
\hline FEN (g/day) & 30.54 & 29.94 & 32.55 & 29.74 & 31.52 & 5.53 & 0.87 & 0.59 & 0.46 & 0.55 \\
\hline UEN (g/day) & 43.43 & 46.05 & 39.18 & 41.81 & 46.05 & 10.14 & 0.98 & 0.54 & 0.46 & 0.57 \\
\hline NB (g/day) & 51.25 & 44.19 & 54.84 & 48.67 & 48.55 & 8.41 & 0.77 & 0.41 & 0.45 & 0.99 \\
\hline UUN (g/day) & 79.29 & 80.55 & 97.86 & 94.61 & 93.06 & 11.19 & 0.28 & 0.17 & 0.71 & 0.91 \\
\hline ENU1 (g/g) & 0.41 & 0.38 & 0.46 & 0.41 & 0.39 & 0.05 & 0.92 & 0.43 & 0.22 & 0.70 \\
\hline ENU2 (g/g) & 0.53 & 0.51 & 0.61 & 0.55 & 0.52 & 0.06 & 0.84 & 0.32 & 0.16 & 0.66 \\
\hline MICEF (g micP/kg TDN) & 151.06 & 150.09 & 135.25 & 135.30 & 136.91 & 14.00 & 0.40 & 0.37 & 0.96 & 0.94 \\
\hline
\end{tabular}

${ }^{1} \mathrm{NC}=$ negative control; $\mathrm{PC}=$ positive control; $\mathrm{LY}=$ live yeast; IY15 = inactive yeast $15 \mathrm{~g} /$ day; IY30 = inactive yeast $30 \mathrm{~g} / \mathrm{day}$.

$\mathrm{NI}$ - nitrogen intake; FEN - fecal excretion of nitrogen; UEN - urinary excretion of nitrogen; NB - nitrogen balance, UUN - urinary urea nitrogen; ENU1 - efficiency of nitrogen utilization in relation to nitrogen intake; ENU2 - efficiency of nitrogen utilization in relation to absorbed nitrogen; MICEF - microbial efficiency; TDN - total digestible nutrients; BD - buffered diets; SE - standard error. 
Utilization of sodium bicarbonate and magnesium oxide as feed additive led to greater $(\mathrm{P}<0.05)$ ruminal $\mathrm{pH}$ than yeast, and IY15 presented greater $(\mathrm{P}<0.05) \mathrm{pH}$ than IY30 (Table 4). Rumen ammonia nitrogen $\left(\mathrm{N}-\mathrm{NH}_{3}\right)$ was increased $(\mathrm{P}<0.05)$ by the use of additives. Feed additives did not influence $(\mathrm{P}>0.05)$ total and individual VFA concentrations as well as acetate to propionate ratio (Table 4). Treatments did not change $(\mathrm{P}>0.05$ ) blood parameters (Table 4$)$.

\section{Discussion}

Yeasts products have been used in ruminant nutrition as feed additives, but the benefits of using live yeasts, and especially the inactive ones, still lack scientific foundation based on in vivo research. The objective of this study was to evaluate the ability of live and inactive yeasts as feed additives in a highconcentrate diet to improve voluntary intake, digestibility coefficients and ruminal parameters.

The experiment was designed to purposely induce a decrease in rumen $\mathrm{pH}$ by the ingestion of a TMR containing $80 \%$ concentrate. However, the ingestion of approximately $20 \%$ NDF in diet was probably enough to stabilize rumen environment, and daily averages of $\mathrm{pH}$ lower than 5.8, to characterize subacute ruminal acidosis (SARA) as described by Beauchemin et al. (2003), were not achieved.

Based on sorting behavior, we could observe that animals presented a preferential intake for NDF (sorting for NDF $=104.2 \%$ ). Allowing refusals between 5 to $10 \%$ probably influenced this behavior, increasing the choice opportunity for animals. Physiologically, this is explained by the minimal total discomfort theory (Forbes, 2007), in which animals control their intake and their choices to minimize the discomfort caused by signals emitted by the body in response to unfavorable situation previously learned.

Even though there were not differences among treatments, it is evident that the greater intake of the fibrous fraction of diet altered the roughage to concentrate ratio actually consumed by animals, especially in NC and IY15 treatment groups. Thus, $\mathrm{pH}$ values were in a normal range, making the use of additives unnecessary. It was postulated by previous research (Arambel and Kent, 1990) that yeasts are more effective under challenge situations. It can explain the lack of influence of yeast in the vast majority of the variables evaluated, since ruminal conditions in this study can be considered normal. Similar issue was described by Monnerat et al. (2013), who credited it to a greater passage rate and

Table 4 - Ruminal and blood parameters of cattle fed the experimental diets

\begin{tabular}{|c|c|c|c|c|c|c|c|c|c|c|c|c|c|}
\hline \multirow{2}{*}{ Variable } & \multicolumn{5}{|c|}{ Treatment $^{1}$} & \multirow{2}{*}{ SE } & \multicolumn{3}{|c|}{ P-value } & \multicolumn{4}{|c|}{ Contrast - P-value } \\
\hline & $\mathrm{NC}$ & PC & LY & IY15 & IY30 & & $\mathrm{T}$ & $\mathrm{TP}$ & $\mathrm{T} \times \mathrm{TP}$ & $\mathrm{NC} \times \mathrm{BD}$ & PC $\times$ Yeast & $L Y \times I Y$ & IY15×IY30 \\
\hline \multicolumn{14}{|c|}{ Ruminal parameters } \\
\hline $\mathrm{pH}$ & 6.22 & 6.20 & 6.02 & 6.17 & 6.00 & 0.15 & 0.01 & $<0.01$ & 0.55 & 0.05 & 0.03 & 0.30 & 0.04 \\
\hline $\mathrm{NH}_{3}-\mathrm{N}(\mathrm{mg} / \mathrm{dL})$ & 9.03 & 13.44 & 11.23 & 11.96 & 12.07 & 1.70 & 0.11 & $<0.01$ & 0.61 & 0.02 & 0.20 & 0.57 & 0.95 \\
\hline $\mathrm{VFA}(\mathrm{mmol} / \mathrm{dL})$ & 9.72 & 10.58 & 9.61 & 9.56 & 10.27 & 0.67 & - & - & - & 0.58 & 0.20 & 0.60 & 0.23 \\
\hline $\begin{array}{l}\text { Acetic acid } \\
(\mathrm{mmol} / 100 \mathrm{mmol})\end{array}$ & 79.27 & 81.48 & 78.06 & 79.66 & 77.34 & 2.16 & - & - & - & 0.92 & 0.09 & 0.79 & 0.19 \\
\hline $\begin{array}{l}\text { Propionic acid } \\
(\mathrm{mmol} / 100 \mathrm{mmol})\end{array}$ & 20.12 & 18.12 & 21.44 & 19.91 & 23.55 & 1.93 & - & - & - & 0.65 & 0.06 & 0.86 & 0.06 \\
\hline $\begin{array}{l}\text { Butyric acid } \\
(\mathrm{mmol} / 100 \mathrm{mmol})\end{array}$ & 0.63 & 0.62 & 0.58 & 0.49 & 0.61 & 0.11 & - & - & - & 0.62 & 0.60 & 0.79 & 0.35 \\
\hline$A: P$ & 4.24 & 4.57 & 3.63 & 4.27 & 3.43 & 0.49 & - & - & - & 0.40 & 0.05 & 0.55 & 0.05 \\
\hline \multicolumn{14}{|c|}{ Blood parameters } \\
\hline Glucose (mg/dL) & 70.88 & 72.66 & 70.93 & 74.31 & 70.90 & 3.78 & 0.42 & 0.01 & 0.53 & 0.44 & 0.73 & 0.38 & 0.12 \\
\hline $\begin{array}{l}\text { Creatinine } \\
(\mathrm{mg} / \mathrm{dL})\end{array}$ & 1.42 & 1.39 & 1.35 & 1.42 & 1.36 & 0.07 & 0.17 & 0.01 & 0.90 & 0.20 & 0.82 & 0.21 & 0.08 \\
\hline Urea $(\mathrm{mg} / \mathrm{dL})$ & 38.11 & 35.24 & 35.65 & 38.19 & 37.92 & 4.21 & 0.40 & 0.01 & 0.95 & 0.40 & 0.23 & 0.18 & 0.90 \\
\hline
\end{tabular}

${ }^{1} \mathrm{NC}=$ negative control; PC = positive control; $\mathrm{LY}=$ live yeast; IY15 = inactive yeast $15 \mathrm{~g} /$ day; IY30 = inactive yeast $30 \mathrm{~g} / \mathrm{day}$.

$\mathrm{NH}_{3}-\mathrm{N}$ - rumen ammonia nitrogen; VFA - volatile fatty acids; A:P - acetate:propionate ratio; $\mathrm{T}$ - treatment; TP = time point $(6.00,12.00,18.00$, and 00:00 h); BD - buffered diets; SE - standard error. 
thus, reduction of the exposure of starch to ruminal microorganisms. Similar to the present research, they observed that the total VFA did not change with the use of additives, which might support the fact that ruminal microbiota had lesser time for starch fermentation in both studies.

We observed a greater $\mathrm{pH}$ in the positive control (4:1 sodium bicarbonate and magnesium oxide) when compared with all evaluated yeasts, and greater pH in IY15 when compared with IY30. Sodium bicarbonate is a buffer present naturally in saliva, and it can affect rumen $\mathrm{pH}$ by neutralization of acidity, sequestering $\mathrm{H}^{+}$and increasing the buffering capacity of ruminal fluid (González et al., 2012). Meanwhile, magnesium oxide is able to increase $\mathrm{pH}$. When this combination is used, a quite acidogenic environment is probably not necessary to its action, as it is for yeast, explaining the greater $\mathrm{pH}$ detected. Regarding the inactive yeast treatments, few data are found in literature about the use of inactive yeast, but it seems contradictory that the lower dosage led to an increase in $\mathrm{pH}$ related to the higher dosage. Results such as this have not been described in literature before. Comparing the sorting activity of these groups, we can observe that, numerically, cows fed IY15 consumed more NDF than those fed IY30, which may have been sufficient to produce statistical differences in $\mathrm{pH}$. Overall, values of ruminal $\mathrm{pH}$ detected in this research are within the range considered as normal (5.5-6.5) for Owens et al. (1997) when high concentrate diets are used.

The use of feed additives increased the amount of ammonia produced in rumen, and $\mathrm{NH}_{3}-\mathrm{N}$ in $\mathrm{NC}$ was smaller than in the other treatments. Considering high-protein level diets, such as the ones used in the present study, the minimum concentration of $\mathrm{NH}_{3}-\mathrm{N}$ required for normal microbial synthesis within rumen is $5 \mathrm{mg} \mathrm{NH}_{3}-\mathrm{N} / \mathrm{dL}$ (Slyter et al., 1979). Thus, we can conclude that rumen microbiota had sufficient $\mathrm{NH}_{3}-\mathrm{N}$ for microbial protein synthesis. Urinary urea excretion values were slightly high (Santos et al., 2001), although serum urea concentrations were within $17-45 \mathrm{mg} / \mathrm{dL}$, considered normal by González and Silva (2006).

Previous research has also concluded that yeast can increase $\mathrm{NH}_{3}-\mathrm{N}$ (Oeztuerk, 2009; Vyas et al., 2014a), but as highlighted by Vyas et al. (2014b), most of the results show no effect (Thrune et al., 2009; Neubauer et al., 2018) or a reduction (Erasmus et al., 1992; Lascano and Heinrichs, 2007) in $\mathrm{NH}_{3}-\mathrm{N}$ by the supplementation with yeasts. There was a decrease in $\mathrm{N}^{-\mathrm{NH}_{3}}$ concentration in relation to control, likely because in lower $\mathrm{pH}$ values, less fibrolytic bacteria will be found in the rumen (Shi and Weimer, 1992). These bacteria require $N$ from ammonia to grow (Demeyer, 1981). Since their population will be smaller, it is expected that $\mathrm{N}-\mathrm{NH}_{3}$ be greater when animals are not supplemented with yeasts or another additive. On the other hand, if yeasts increase $\mathrm{NH}_{3}-\mathrm{N}$, the mechanisms by which it happens are not elucidated; it might be because of its capacity of provide stimulatory factors (Oeztuerk, 2009) and even protein (Miller-Webster et al., 2002; Oeztuerk, 2009) for rumen bacteria, or by changes in abundance of microorganisms with proteolytic activity (Yoon and Stern, 1996).

In this research, we still could not guarantee the effectiveness of yeasts, but we could elucidate some crucial points that will aid future studies. We highlighted that allowing refusals between 5 and $10 \%$ was not appropriate, since it may increase the preferential intake of fibrous particles by animals. Therefore, adjusting daily intake for $5 \%$ of refusals would be a better strategy. In addition, as discussed before, it is necessary to ensure an acidogenic rumen environment, which we could not do with $80 \%$ concentrate diet. Thus, we would encourage further research on this topic, as long as these comments are considered during the experiment designing.

\section{Conclusions}

Active and inactive yeasts have potential to modify ruminal traits, especially by increasing ruminal ammonia. Nevertheless, because of the sorting behavior observed, we do not recommend these yeasts as feed additives for bovines fed diets with $80 \%$ concentrate. In this situation, animals are able to select fibrous particles from total mixed ration, and no representative gain in ruminal parameters and digestibilities are guaranteed. 


\section{Conflict of Interest}

The authors declare no conflict of interest.

\section{Author Contributions}

Conceptualization: C.S. Cunha, L.S. Knupp and C.M. Veloso. Data curation: C.S. Cunha, A.L. Silva, T.R.S. Gionbelli, M.A.S. Novaes and G.F. Virginio Júnior. Formal analysis: C.S. Cunha, M.I. Marcondes, A.L. Silva, T.R.S. Gionbelli, M.A.S. Novaes and G.F. Virginio Júnior. Funding acquisition: L.S. Knupp and C.M. Veloso. Investigation: C.S. Cunha and M.I. Marcondes. Methodology: C.S. Cunha and C.M. Veloso. Project administration: C.M. Veloso. Writing-original draft: C.S. Cunha and M.I. Marcondes. Writing-review \& editing: C.S. Cunha, M.I. Marcondes, A.L. Silva and C.M. Veloso.

\section{Acknowledgments}

We would like to acknowledge the governmental agencies Conselho Nacional de Desenvolvimento Científico e Tecnológico (CNPq) and Coordenação de Aperfeiçoamento de Pessoal de Nível Superior (CAPES), for funding this research.

\section{References}

Arambel, M. J. and Kent, B. A. 1990. Effect of yeast culture on nutrient digestibility and milk yield response in early to midlactation dairy cows. Journal of Dairy Science 73:1560-1563. https://doi.org/10.3168/jds.S0022-0302(90)78825-X

AOAC - Association of Official Analytical Chemistry. 1990. Official methods of analysis. 15th ed. AOAC International, Arlington, VA.

AOAC - Association of Official Analytical Chemistry. 2006. Official methods of analysis. 18th ed. AOAC International, Gaithersburg, MD.

Barbosa, A. M.; Valadares, R. F. D.; Valadares Filho, S. C.; Pina, D. S.; Detmann, E. and Leão, M. I. 2011. Endogenous fraction and urinary recovery of purine derivates obtained by different methods in Nellore cattle. Journal of Animal Science 89:510-519. https://doi.org/10.2527/jas.2009-2366

Beauchemin, K. A.; Yang, W. Z. and Rode, L. M. 2003. Effects of particle size of alfalfa-based dairy cow diets on chewing activity, ruminal fermentation, and milk production. Journal of Dairy Science 86:630-643. https://doi.org/10.3168/jds. S0022-0302(03)73641-8

Callaway, T. S. and Martin, S. A. 1997. Effects of a Saccharomyces cerevisiae culture on ruminal bacteria that utilize lactate and digest cellulose. Journal of Dairy Science 80:2035-2044.

Chaney, A. L. and Marbach, E. P. 1962. Modified reagents for determination of urea and ammonia. Clinical Chemistry 8:130-132.

Chaucheyras, F.; Fonty, G.; Bertin, G.; Salmon, J. M. and Gouet, P. 1996. Effects of a strain of Saccharomyces cerevisiae (LevucellSC), a microbial additive for ruminants, on lactate metabolism in vitro. Canadian Journal of Microbiology 42:927-933.

Chen, X. B. and Gomes, M. J. 1992. Estimation of microbial protein supply to sheep and cattle based on urinary excretion of purine derivatives - an overview of technical details. International Feed Resources Unit. Rowett Research Institute, Aberdeen. (Occasional publication). 21p.

Chung, Y. H.; Walker, N. D.; McGinn, S. M. and Beauchemin, K. A. 2011. Differing effects of 2 active dried yeast (Saccharomyces cerevisiae) strains on ruminal acidosis and methane production in nonlactating dairy cows. Journal of Dairy Science 94:2431-2439. https://doi.org/10.3168/jds.2010-3277

Demeyer, D. I. 1981. Rumen microbes and digestion of plant cell walls. Agriculture and Environment 6:295-337. https://doi.org/10.1016/0304-1131(81)90020-5

Detmann, E.; Souza, M. A. and Valadares Filho, S. C. 2012. Métodos para análises de alimentos. Detmann, E.; Souza, M. A. and Valadares Filho, S. C., eds. Suprema, Visconde do Rio Branco.

Detmann, E. and Valadares Filho, S. C. 2010. On the estimation of non-fibrous carbohydrates in feeds and diets. Arquivo Brasileiro de Medicina Veterinária e Zootecnia 62:980-984. https://doi.org/10.1590/S0102-09352010000400030

Dawson, K. A.; Newman, K. E. and Boling, J. A. 1990. Effects of microbial supplements containing yeast and lactobacilli on roughage-fed ruminal microbial activities. Journal of Animal Science 68:3392-3398. https://doi. org/10.2527/1990.68103392x 
Erasmus, L. J.; Botha, P. M. and Kistner, A. 1992. Effect of yeast culture supplement on production, rumen fermentation, and duodenal nitrogen flow in dairy cows. Journal of Dairy Science 75:3056-3065. https://doi.org/10.3168/jds.S00220302(92)78069-2

Forbes, J. M. 2007. A personal view of how ruminant animals control their intake and choice of food: Minimal total discomfort. Nutrition Research Reviews 20:132-146. https://doi.org/10.1017/S0954422407797834

Fujihara, T.; Orskov, E. R.; Reeds, P. J. and Kyle, D. J. 1987. The effect of protein infusion on urinary excretion of purine derivatives in ruminants nourished by intragastric nutrition. Journal of Agricultural Science 109:7-12. https://doi. org/10.1017/S0021859600080916

González, F. H. D. and Silva, S. C. 2006. Introdução à bioquímica clínica veterinária. 2.ed. Editora da UFRGS, Porto Alegre.

González, L. A.; Manteca, X.; Calsamiglia, S.; Schwartzkopf-Genswein, K. S. and Ferret, A. 2012. Ruminal acidosis in feedlot cattle: Interplay between feed ingredients, rumen function and feeding behavior (a review). Animal Feed Science and Technology 172:66-79. https://doi.org/10.1016/j.anifeedsci.2011.12.009

Guedes, C. M.; Gonçalves, D.; Rodrigues, M. A. M. and Dias-da-Silva, A. 2008. Effects of a Saccharomyces cerevisiae yeast on ruminal fermentation and fibre degradation of maize silages in cows. Animal Feed Science and Technology 145:27-40. https://doi.org/10.1016/j.anifeedsci.2007.06.037

Lascano, G. J. and Heinrichs, A. J. 2007. Yeast culture (Saccharomyces cerevisiae) supplementation in growing animals in the dairy industry. CAB Reviews: Perspectives in Agriculture, Veterinary Science, Nutrition and Natural Resources 2:049.

Leonardi, C. and Armentano, L. E. 2003. Effect of quantity, quality, and length of alfalfa hay on selective consumption by dairy cows. Journal of Dairy Science 86:557-564. https://doi.org/10.3168/jds.S0022-0302(03)73634-0

Licitra, G.; Hernandez, T. M. and Van Soest, P. J. 1996. Standardization of procedures for nitrogen fractionation of ruminant feeds. Animal Feed Science and Technology 57:347-358. https://doi.org/10.1016/0377-8401(95)00837-3

Malcolm, K. J. and Kiesling, H. E. 1990. Effects of whole cottonseed and live yeast culture on ruminal fermentation and fluid passage rate in steers. Journal of Animal Science 68:1965-1970. https://doi.org/10.2527/1990.6871965x

Michalet-Doreau, B.; Morand, D. and Martin, C. 1997. Effect of the microbial additive Levucell ${ }^{\circledR}$ SC on microbial activity in the rumen during the stepwise adaptation of sheep to high concentrate diet. Reproduction Nutrition Development, EDP Sciences 37(Suppl):81-82.

Miller-Webster, T.; Hoover, W. H.; Holt, M. and Nocek, J. E. 2002. Influence of yeast culture on ruminal microbial metabolism in continuous culture. Journal of Dairy Science 85:2009-2014.

Monnerat, J. P. I. S.; Paulino, P. V. R.; Detmann, E.; Valadares Filho, S. C.; Valadares, R. D. F. and Duarte, M. S. 2013. Effects of Saccharomyces cerevisiae and monensin on digestion, ruminal parameters, and balance of nitrogenous compounds of beef cattle fed diets with different starch concentrations. Tropical Animal Health and Production 45:1251-1257. https://doi.org/10.1007/s11250-013-0356-9

Neubauer, V.; Petri, R.; Humer, E.; Kröger, I.; Mann, E.; Reisinger, N.; Wagner, M. and Zebeli, Q. 2018. High-grain diets supplemented with phytogenic compounds or autolyzed yeast modulate ruminal bacterial community and fermentation in dry cows. Journal of Dairy Science 101:2335-2349. https://doi.org/10.3168/jds.2017-13565

NRC - National Research Council. 2000. Nutrient requirements of beef cattle. 7th ed. Washington, DC.

Oeztuerk, H.; Schroeder, B.; Bayerbach, M. and Breves, G. 2005. Influence of living and autoclaved yeasts of Saccharomyces boulardii on in vitro ruminal microbial metabolism. Journal of Dairy Science 88:2594-2600. https://doi.org/10.3168/jds. S0022-0302(05)72935-0

Oeztuerk, H. 2009. Effect of live and autoclaved yeast cultures on ruminal fermentation in vitro. Journal of Animal and Feed Sciences 18:142-150. https://doi.org/10.22358/jafs/66378/2009

Opsi, F.; Fortina, R.; Tassone, S.; Bodas, R. and López, S. 2012. Effects of inactivated and live cells of Saccharomyces cerevisiae on in vitro ruminal fermentation of diets with different forage: concentrate ratio. The Journal of Agricultural Science 150:271-283. https://doi.org/10.1017/S0021859611000578

Owens, F. N.; Secrist, D. S.; Hill, W. J. and Gill, D. R. 1997. The effect of grain source and grain processing on performance of feedlot cattle: a review. Journal of Animal Science 75:868-879. https://doi.org/10.2527/1997.753868x

Santos, T. G.; Cavalieri, F. L. B. and Modesto, E. C. 2001. Recentes avanços em nitrogênio não proteico na nutrição de vacas

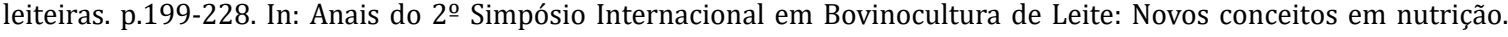
Universidade Federal de Lavras, Lavras.

Shi, Y. and Weimer, P. J. 1992. Response surface analysis of the effects of $\mathrm{pH}$ and dilution rate on Ruminococcus flavefaciens FD-1 in cellulose-fed continuous culture. Applied Environmental Microbiology 58:2583-2591.

Siegfried, B. R.; Ruckemann, H. and Stumpf, G. 1984. Method for the determination of organic acids in silage by high performance liquid chromatography. Landwirtsch. Forsch. 37:298-304.

Silva, A. L.; Detmann, E.; Dijkstra, J.; Pedroso, A. M.; Silva, L. H. P.; Machado, A. F.; Sousa, F. C.; dos Santos, G. B. and Marcondes, M. I. 2018. Effects of rumen-undegradable protein on intake, performance, and mammary gland development 
in prepubertal and pubertal dairy heifers. Journal of Dairy Science 101:5991-6001. https://doi.org/10.3168/jds.201713230

Silva, L. F. C.; Valadares Filho, S. C.; Chizzotti, M. L.; Rotta, P. P.; Prados, L. F.; Valadares, R. F. D.; Zanetti, D. and Braga, J. M. S. 2012. Creatinine excretion and relationship with body weight of Nellore cattle. Revista Brasileira de Zootecnia 41:807-810. https://doi.org/10.1590/S1516-35982012000300046

Slyter, L. L.; Satter, L. D. and Dinius, D. A. 1979. Effect of ruminal ammonia concentration on nitrogen utilization by steers. Journal of Animal Science 48:906-912. https://doi.org/10.2527/jas1979.484906x

Thrune, M.; Bach, A.; Ruiz-Moreno, M.; Stern, M. D. and Linn, J. G. 2009. Effects of Saccharomyces cerevisiae on ruminal $\mathrm{pH}$ and microbial fermentation in dairy cows: Yeast supplementation on rumen fermentation. Livestock Science 124:261-265. https://doi.org/10.1016/j.livsci.2009.02.007

Valadares, R. F. D.; Broderick, G. A.; Valadares Filho, S. C. and Clayton, M. K. 1999. Effect of replacing alfalfa silage with high moisture corn on ruminal protein synthesis estimated from excretion of total purine derivatives. Journal of Dairy Science 82:2686-2696. https://doi.org/10.3168/jds.S0022-0302(99)75525-6

Vyas, D.; Uwizeye, A.; Mohammed, R.; Yang; W. Z.; Walker, N. D. and Beauchemin, K. A. 2014a. The effects of active dried and killed dried yeast on subacute ruminal acidosis, ruminal fermentation, and nutrient digestibility in beef heifers. Journal of Animal Science 92:724-732. https://doi.org/10.2527/jas.2013-7072

Vyas, D.; Uwizeye, A.; Yang, W. Z. and Beauchemin, K. A. 2014b. Importance of yeast viability for reducing the effects of ruminal acidosis in beef heifers during and following an imposed acidosis challenge. Animal Feed Science and Technology 197:103-113. https://doi.org/10.1016/j.anifeedsci.2014.09.004

Wallace, R. J. 1996. The mode of action of yeast culture in modifying rumen fermentation. p.217-232. In: Biotechnology in feed industry. Alltech Inc., Nottingham University Press, Nottingham, UK.

Williams, P. E.; Tait, C. A. G.; Innes, G. M. and Newbold, C. J. 1991. Effects of the inclusion of yeast culture (Saccharomyces cerevisiae plus growth medium) in the diet of dairy cows on milk yield and forage degradation and fermentation patterns in the rumen of steers. Journal of Animal Science 69:3016-3026. https://doi.org/10.2527/1991.6973016x

Yoon, I. K. and Stern, M. D. 1996. Effects of Saccharomyces cerevisiae and Aspergillus oryzae cultures on ruminal fermentation in dairy cows. Journal of Dairy Science 79:411-417. 